The Spectrum of

\title{
NREL Helps Clean Cities Displace Billions of Gallons of Petroleum, One Vehicle at a Time
}

Clean Energy Innovation

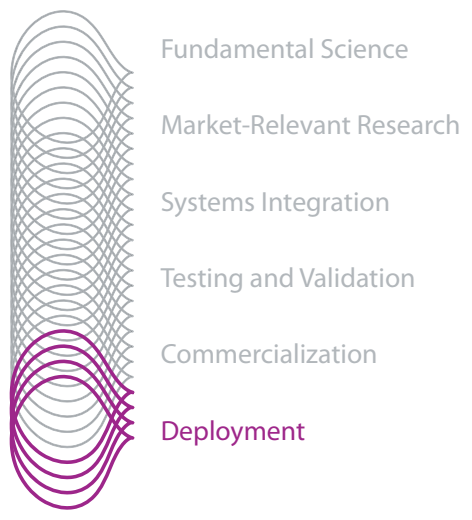
Laboratory (NREL). An initiative of the U.S. Department of Energy (DOE), Clean Cities creates public-private partnerships with a common mission: to reduce petroleum consumption in the transportation sector. Since the inception of Clean Cities in 1993, NREL has played a central role in supporting the program, an effort that stems from the laboratory's strategy to put scientific innovation into action in the marketplace.

\section{Creating a Market for Alternative Fuels}

It's late in the afternoon and commuters at Los Angeles International Airport board a compressed natural gas shuttle. At the same time, in Gary, Indiana, travelers fill up their flexiblefuel vehicles with E85, a blend of 85\% ethanol and 15\% gasoline, confident in the availability of ethanol stations along the 800 -mile route to Mobile, Alabama. On a daily basis, NREL supports these and hundreds of other local, grassroots initiatives that mark the petroleumreduction reformation spreading across the nation as part of the Clean Cities program.

Clean Cities builds value by expanding the market for advanced transportation at a local level through voluntary coalitions. These coalitions, led by Clean Cities coordinators, draw stakeholders from transportation departments, commercial fleets, transit agencies, car dealers,

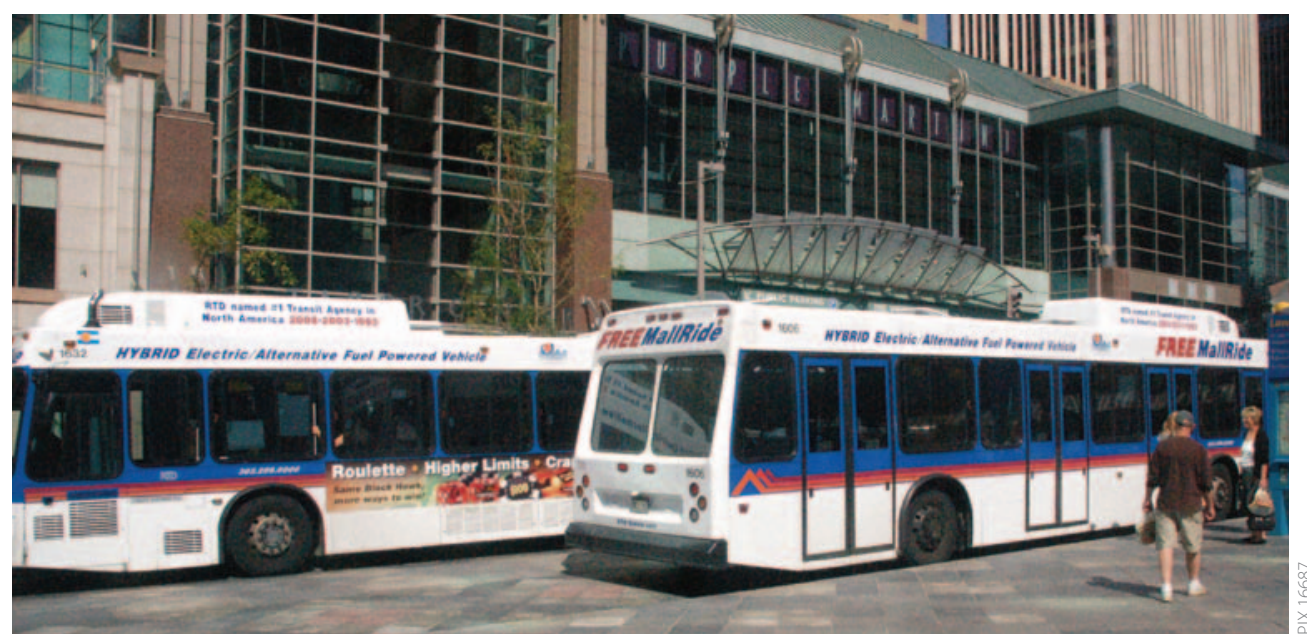

One of the Clean Cities Program's success stories is Denver's Regional Transit District, which employs hybrid-electric buses fueled with Compressed Natural Gas (CNG) for a shuttle service running along its open-air 16th Street Mall. Credit: Trish Cozart, NREL

Through deep technical expertise and an unmatched breadth of capabilities, NREL leads an integrated approach across the spectrum of renewable energy innovation. From scientific discovery to accelerating market deployment, NREL works in partnership with private industry to drive the transformation of our nation's energy systems.

This case study illustrates NREL's innovations in Deployment.

\section{BNREL \\ NATIONAL RENEWABLE ENERGY LABORATORY}

NREL is a national laboratory of the U.S. Department of Energy, Office of Energy Efficiency and Renewable Energy, operated by the Alliance for Sustainable Energy, LLC. 
fuel suppliers, public utilities, and nonprofit associations. Coalitions provide a forum for members to leverage their resources, develop joint projects, collaborate on public policy issues, and promote petroleum reduction technologies.

"The Clean Cities program is all about bringing technical expertise out of the lab and into local markets," says NREL's Clean Cities Task Leader Wendy Dafoe.

Over the last 15 years, the number of coalitions has expanded to nearly 90 , covering areas where 229 million U.S. citizens live-approximately $78 \%$ of the country's total population. And more than 6,500 stakeholders have accepted the invitation to support the partnership's mission.

\section{Providing Technical Expertise to Clean Cities Coordinators}

"Renewable energy in the transportation sector is a unique challenge because making a large-scale impact involves influencing thousands_even millions_of individual decisions," says Margo Melendez, NREL's Clean Cities Supervisor.

Clean Cities coordinators help guide these decisions but are often the lone representatives of Clean Cities coalitions covering a large area. Coordinators rely on resources and support from NREL to help them promote the business proposition of clean transportation solutions.

"I couldn't do my job without the technical support and analytical tools provided by NREL," says Kellie Walsh, executive director of the Greater Indiana Clean Cities Coalition.

NREL's Clean Cities team educates coalitions and their coordinators about program resources, financial opportunities, and fuel and vehicle technology basics through workshops, online courses, outreach publications, presentations, technical assistance, and Web sites. In 2009, users accessed 4.3 million pages of information on the Alternative Fuels and Advanced Vehicles Data Center (AFDC) and Clean Cities Web sites, which are produced by NREL. This unbiased supply of information provides coordinators, stakeholders, and consumers with the opportunity to make informed decisions about their transportation options. The Web sites also contain NREL's line of analysis tools to help coordinators demonstrate the economic viability of various alternative fuel and vehicle options and help stakeholders realize not only the cost savings but also the environmental benefits these options provide.

\section{Displacing Petroleum Consumption}

Clean Cities' coalitions have made steady progress in displacing petroleum used in the transportation sector. In 2009 alone, roughly 446 million gallons of gasoline were displaced as the result of Clean Cities activities.

The benefits of displacing petroleum are appealing, both environmentally and economically. Not only does petroleum reduction ease greenhouse gas emissions, but it also supports the growing alternative fuel business in the United States. Clean Cities coalitions have put more than 600,000 alternative fuel vehicles on the road and added more than 1,900 alternative fueling stations.

Participation in the Clean Cities program continues to grow nationwide as communities, states, fleets, fuel providers, and vehicle manufacturers look for venues to build relationships and develop joint projects. Momentum is growing in the development of fuel infrastructure to take advantage of the inventory of alternative fuel vehicles that now exists in many areas. Program participants see the Clean Cities program and the resources NREL provides as natural places to begin to explore new fuels and advanced technologies.

\section{Helping Drivers Find Alternative Fuel Stations}

NREL's Clean Cities team helps to build the market for alternative fuel vehicles by making them easier to use. For example, driving cross-country or even around town in an alternative fuel vehicle used to require advanced planning to find alternative fuel stations along the way, but not anymore. Drivers can now find stations on the go, using a cell phone or other mobile device with Internet access, thanks to the Mobile Alternative Fueling Station Locator.

Developed by NREL, the locator allows drivers to find biodiesel, electric, E85, hydrogen, natural gas, and propane fueling sites. Users simply select a fuel type and enter a location to find the five closest stations. The easy-to-navigate interface automatically generates maps to fueling sites and provides contact information and hours of operation.

The mobile locator pulls data from DOE's Alternative Fueling Station Locator, a comprehensive online tool that's been available via the Alternative Fuels and Advanced Vehicles Data Center for years. The mobile locator uses a subset of the original tool's functionality and converts it for use with handheld devices.

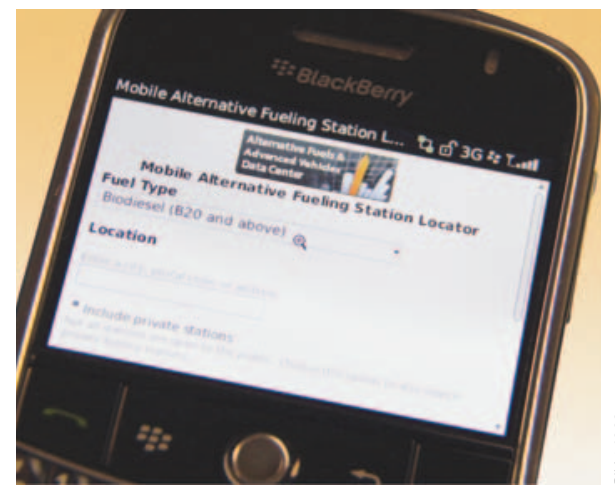

Credit: Heather Lammers, NREL

\section{National Renewable Energy Laboratory}

1617 Cole Boulevard

Golden, Colorado 80401

303-275-3000 • www.nrel.gov

NREL is a national laboratory of the U.S. Department of Energy, Office of Energy Efficiency and Renewable Energy, operated by the Alliance for Sustainable Energy, LLC.

\section{NREL/FS-6A42-48936 • October 2010}

Printed with a renewable-source ink on paper containing at least $50 \%$ wastepaper, including $10 \%$ post consumer waste. 